\title{
Socioeconomics Factors Associated with the Utilization of Primary Health Servicesof Mothers and Children at Nunukan District, North Kalimantan
}

\author{
Yunita Kristiani' ${ }^{1)}$, Didik Tamtomo²), Mahendra Wijaya ${ }^{3)}$ \\ 1)Masters Program in Public Health, Universitas Sebelas Maret \\ 2)Faculty of Medicine, Universitas Sebelas Maret \\ 3)Faculty of Social and Political Sciences, Universitas Sebelas Maret
}

\begin{abstract}
Background: One of the main health development agenda in Indonesia 2015 to 2019 is reduction in maternal mortality ratio and infant mortality rate, and improve access and quality of maternal and child health services. However, variance in socioeconomics status between individual and between rural-urban have caused to difference in utilization of health service. This study aimed to analyze socioeconomics factors associated with the utilization of primary health services of mothers and childrenat Nunukan District, North Kalimantan.

Subjects and Method: This was an analytic observational study with cross-sectional design. The study was conducted at six community health centers in Nunukan, North Kalimantan, from October to November, 2017. A total sample of 208 mothers was collected using stratified multistage random sampling. The dependent variables were antenatal care (ANC) service, place of birth delivery, and basic immunization. The independent variables were maternal education, maternal employment status, family income, family welfare, and residence. The data were collected by questionnaire and analyzed by path analysis.

Results: Utilization of ANC increased with better family welfare $(b=1.42 ; 95 \% \mathrm{CI}=0.34$ to 2.49 ; $\mathrm{p}=0.010)$. Use of basic immunization increased with higher maternal education $(\mathrm{b}=0.71 ; 95 \% \mathrm{CI}=$ 0.06 to 1.35; $\mathrm{p}=0.032$ ). Place of birth delivery at formal health facility increased with living in urban area $(\mathrm{b}=3.2 ; 95 \% \mathrm{CI}=1.97$ to $4.44 ; \mathrm{p}<0.001)$, maternal employment $(\mathrm{b}=2.34 ; 95 \% \mathrm{CI}=0.77$ to $3.91 ; \mathrm{p}=0.003)$, and regular $\mathrm{ANC}(\mathrm{b}=1.04 ; 95 \% \mathrm{CI}=-0.10$ to $2.18 ; \mathrm{p}=0.074)$. Family income increased with higher maternal education level $(b=1.21 ; 95 \% \mathrm{CI}=0.50$ to1.92; $\mathrm{p}=0.001)$ and maternal employment $(\mathrm{b}=2.54 ; 95 \% \mathrm{CI}=1.67$ to $3.41 ; \mathrm{p}<0.001)$. Family welfare increased with living in urban area $(b=1.4 ; 95 \% \mathrm{CI}=0.09$ to $2.68 ; \mathrm{p}=0.035)$ and higher family income $(\mathrm{b}=2.5 ; 95 \%$ $\mathrm{CI}=0.44$ to $4.54 ; \mathrm{p}=0.017)$. Maternal employment status increased with higher maternal education level $(\mathrm{b}=2.45 ; 95 \% \mathrm{CI}=1.63$ to $3.26 ; \mathrm{p}<0.001)$.

Conclusion: Utilization of ANC directly increases with better family welfare.Utilization of basic immunization increases with highermaternaleducation. Place of birth delivery at formal health facility increases with living in urban area, maternal employment, and regular ANC.
\end{abstract}

Keyword: social economics factors, ANC, place of birth delivery, basic immunization, mother, children

\section{Correspondence:}

Yunita Kristiani. Masters Program in Public Health, Universitas Sebelas Maret, Jl. Ir. Sutami 36 A, Surakarta 57126, Central Java. Email: y.ithakristiani@gmail.com. Mobile: 085393313553.

\begin{tabular}{l}
\hline \multicolumn{3}{c}{ BACKGROUND } \\
\hline Based on the data from Indonesia \\
Demographic Health Survey (Statistics \\
Center, 2012), Maternal Mortality Rate \\
(MMR) increased from 228 (2007) to 359 \\
(2012) per 100,00o live births, while Infant
\end{tabular}

Mortality Rate (IMR) although showed a decrease from 34 (2007) to 32 (2012) per 1,000 life percentages, it experienced a slowdown. Efforts to decrease MMR and IMR can be done through access to quality maternal and children/infants health 
services, starting from antenatal care, health assistance by trained health personnel and basic immunization for infants (Ministry of Health, 2014), especially in border, outer, and remote areas outside Java-Bali. This is due to the lack of road infrastructure, electricity, and telecommunication infrastructure, which can affect economic disparities and public services (eg health) between regions (Ministry of Village, Development of Disadvantaged Region and Transmigration of the Republic of Indonesia, 2015).

One of the districts that neededmore attention was Nunukan District in North Kalimantan Province, which is a boarder regencyin the youngest province that is currently active in developing the region to catch up with other provinces in Indonesia. By 2015, the number of maternal mortality in Nunukan District has reached 7 cases (Health Office of North Kalimantan, 2016). Meanwhile, infant mortality in Nunukan District increased from 32 (2015) to 57 babies (2016) (Health Department Nunukan, 2016). The coverage of ante-natal care (ANC) of the fourth visit (K4) in 2016 reached only $83.1 \%$ of the total number of pregnant women in Nunukan District, it was slightly lower than that of Indonesian K4 reaching $85.06 \%$ (Ministry of Health, 2016). The target of $\mathrm{K}_{4}$ pregnant women visit in Minimum Service Standard is $95 \%$ (Ministry of Health, 2008).

The coverage of childbirth assisted by skilled health personnel in 2016 was only 78.9\% (Health Center Office of Nunukan, 2016) in which it decreased compared to the coverage in 2014, which reached 87.05\% (Ministry of Health, 2016). Pusdatin (2016) showed that of the 87.05\% of delivery coverage in Nunukan district in 2014 assisted by health personnel, only $70.91 \%$ gave birth with health facilities, it was less than the coverage of labor in
Indonesian health facilities which reached $78.80 \%$, while $16.14 \%$ Nunukan women gave birth home. This showsthat there were still many women who chose to give birth at home rather than giving birth using health facilities. Whereas birth place can be an indirect cause of maternal mortality (Ministry of Health, 2014).

The coverage of complete basic immunization in infants in Nunukan District in 2016 was only $67.5 \%$ of 4,080 babies. It was lower than the coverage of Indonesia's complete basic immunization which was about $91.1 \%$. The data shows that there were still 1,325 infants who did not get basic immunization in Nunukan District (Health Center of Nunukan, 2016, Ministry of Health, 2017).

The high rate of MMR and IMR can be because of the differences in the use of health services. This difference is mainly due to socio-economic differences in society, such as welfare and family income, as well as the level of maternal education. IMR in poor households is more than twice that of the IMR in the wealthiest households. Similarly, educational influence, during the period 1998-2007 IMR in uneducated mothers was 73 per 1,00o live births, whereas in mothers with upper secondary education was 24 per 1,00o live births. This indicates that the higher the socio-economic level of a person, the higher the use of health services (Unicef, 2012).

In addition to the socioeconomic level, MMR and MMR are also detected between the mother residence area which are the urban-village areas. The IDHS 2012 report shows that the coverage of pregnancy check up was higher in urban areas than in rural areas (98\% and 93\%) (Bappenas, 2013). Similarly, for the coverage of deliveries in health facilities, in urban areas reached $80 \%$, while in rural areas, it was only $46.7 \%$ (Statistics Center, 
2012). Maternal mortality and infant mortality should be prevented by improving the effectiveness and quality of services to mothers and children, with a focus on reducing village-city differences, socioeconomic levels, and ensuring the allocation of health resources to community groups that need it such as ANC services, postpartum care by skilled workers at health facilities and basic immunization for infants.

Based on the reasons mentioned above, the researcher aims at analysing socio-economic factors influencing the use of primary health services on mothers and infants in community health centers in Nunukan regency.

\section{SUBJECTS AND METHODS \\ 1. Study Design \\ This was an analytic observational study with a cross sectional design. The study was conducted from October to November 2017.}

\section{Population and Sampel}

The population was all mothers with $\leq 12$ months old baby in Nunukan District. This research used stratified multistage random sampling technique. Sub-district selection was done using stratification of urban-rural area, which was three Public Health Centers in urban areas and three other in rural areas. The selection of research subjects was randomly assigned. In each sub-district, three villages were taken randomly. Then, in selected villages, 11-12 samples were taken, so the total samples were 208 people.

Public Health Services in urban areas were areas that meet at least three out of four criteria, including: 1) activities of more than $50 \%$ of the population working in nonagrarian sectors, especially industry, trade, and services; 2) having urban facilities, such as school which is located about 2.5 $\mathrm{km}$ from the place, market ( $2 \mathrm{~km})$, hospital (less than $5 \mathrm{~km}$ ), cinema, or hotel; 3) more than $90 \%$ of households have electricity; 4) there is highway access and transportation to urban facilities. The selected Public Health Centers are Nunukan PHC, Sedadap PHC and Sungai Nyamuk PHC.

Rural areas public health centers are areas that meet at least threeout of four criteria, they are: 1 ) the activities of $\geq 50 \%$ of the population was in the agrarian sector; 2) they have facilities, such as school which is located more than $2.5 \mathrm{~km}$ from the place, market and urban cities(more than 2 $\mathrm{km}$ ), hospital (more than $5 \mathrm{~km}$ ), and do not have the facilities of cinema or hotel; 3) households with electricity were less than $90 \%$; 4) there is an access to roads and transportation to facilities such as markets, hospitals, schools, and so on. The selected Rural Public Health Center was Sebuku PHC, Tulin Onsoi PHC, and Sembakung PHC.

\section{Study Variables}

The dependent variables were the use of ANC service, the choice of where to have the birth delivery and basic immunization. The independent variables were educational background, job, family income, family and community/society welfare.

\section{Variables Operational Definitions}

Educational was defined as the highest formal education status ever pursued through a structured and tiered education pathway, judged by the last certificate earned. The data were collected by questionnaire. The measurement scale was categorical.

Occupation was defined as a kind of daily work done to help the family economy. The data were collected by questionnaire. The measurement scale was categorical.

Family income was defined as the amount of income received by the whole family (husband, wife or children who are already working). The data were collected 
by questionnaire. The measurement scale was continuous.

Family welfare was defined as whether a family is able to fulfil the needs of decent living without experiencing limitations to access goods and services.

Residential area was defined as where families live and daily activities, both socioeconomic and cultural. The data were collected by questionnaire. The measurement scale was categorical.

Antenatal Care (ANC) was defined as an examination performed during pregnancy by competent health personnel. The data were collected by questionnaire. The measurement scale was continuous.

Place of birth was defined as the location where the birth delivery takes place. The data were collected by questionnaire. The measurement scale was categorical.

Basic immunization was defined as the provision of immunization in infants according to the schedule and age of infants, starting at after the birth delivery until one year old to achieve immunity against certain diseases. The data were collected by questionnaire. The measurement scale was categorical.

\section{Data Collections}

The data were collected using questionnaires in the form of checklists about the educational background, occupation, family income, living area/residence, and SocioEconomic Population Data Collection 2005 (PSE05) from Statistics center to measure the family welfare.

\section{Data Analysis}

The data analysis used in this studywas path analysis with STATA 13 program. Path analysis presents an applied form of multi regression analysis using complex path lines so it can be used to calculate the magnitude of the direct influence of every exogenous variable to endogenous varia- bles. The influence in variables can be seen as path coefficients which were standardized regression coefficients.

\section{Research Ethics}

The research ethical clearance was obtained from the Research Ethics Committee at Dr. Moewardi Hospital, Surakarta, Central Java, Indonesia. Research ethics included issues such as informed consent, anonimity, confidentiality, and ethical clearance.

\section{RESULTS}

\section{Univariate Analysis}

Table 1 shows that $52.4 \%$ of samples have higher education level. A total of $69.7 \%$ of research subjects work at home. There was $55.8 \%$ of the subjects whose family income $<$ UMP.

A total of $90.9 \%$ of the subjects belong to the criteria of prosperous families. A total of $88 \%$ of the subjects had used ANC services $\geq 4$ times. A total of $72.6 \%$ of samples have chosen health facilities as the place for doing the birth delivery, and $75.5 \%$ of the samples provided a complete basic immunization to their infants based on their age.

\section{Bivariate Analysis}

Bivariate analysis describes the influence of one independent variable to one dependent variable. Independent variables in this research are education level, occupation, family income, family welfare and residence area. The method used was Chi Square test.

Table 2 displays the results of bivariate analysis of factors that affect the selection of birth delivery places. Level of education (OR $=5.21, \mathrm{p}<0.001)$, employment $(\mathrm{OR}=18.63, \mathrm{p}<0.001)$, family income $(\mathrm{OR}=3.71 ; \mathrm{p}<0.001)$, family welfare $(\mathrm{OR}=5.48 ; \mathrm{p}=0.001)$ living $(\mathrm{OR}=$ 36.36; $\mathrm{p}<0.001$ ) had effects on improving the choice of delivery and was statistically significant. 
Table 3 shows the results of bivariate analysis of factors that affect the completeness of immunization in infants. Level of education $(\mathrm{OR}=2.02 ; \mathrm{p}=0.045)$, employment $(\mathrm{OR}=3.48 ; \mathrm{p}=0.005)$, family

Table 1. The Characteristics of Study Subjects

\begin{tabular}{llcc}
\hline \multicolumn{1}{c}{ Variables } & \multicolumn{1}{c}{ Categories } & Total & Percentage (\%) \\
\hline Education background level & Low & 99 & 47.6 \\
& High & 109 & 52.4 \\
Occupation & Working at home & 145 & 69.7 \\
Family Income & Working outside of home & 63 & 30.3 \\
& < minimum regional wage & 116 & 55.8 \\
Family Prosperity & $\geq$ minimum regional wage & 92 & 44.2 \\
\multirow{2}{*}{ Residence Area } & Poor & 19 & 9.1 \\
& Prosperous & 189 & 90.9 \\
ANC & Rural Areas & 104 & 50 \\
& Urban Areas & 104 & 50 \\
Birth Delivery Places & <4x during pregnancy & 25 & 12 \\
\multirow{2}{*}{ Basic Immunization } & Hx during pregnancy & 183 & 88 \\
& Home & 57 & 27.4 \\
& Health Facilities & 151 & 72.6 \\
\hline
\end{tabular}

Table 2. The bivariate analysis of the effect of socio-economic factors on the selection of birth delivery places

\begin{tabular}{|c|c|c|c|c|c|c|c|c|}
\hline \multirow{3}{*}{ Variables } & \multirow{3}{*}{ Categories } & \multicolumn{4}{|c|}{ Birth Delivery Places } & \multirow{3}{*}{ OR } & \multirow{3}{*}{$95 \%$ CI } & \multirow{3}{*}{$\mathbf{p}$} \\
\hline & & \multicolumn{2}{|c|}{ Home } & \multicolumn{2}{|c|}{ Health facility } & & & \\
\hline & & $\mathbf{n}$ & $\%$ & $\mathbf{n}$ & $\%$ & & & \\
\hline Education & Low & 43 & 43.4 & 56 & 56.6 & 5.21 & 2.62 to 10.36 & $<0.001$ \\
\hline Background & High & 14 & 12.8 & 95 & 87.2 & & & \\
\hline \multirow[t]{2}{*}{ Occipation } & Working at home & 55 & 37.9 & 90 & 62.1 & 18.63 & 4.38 to 79.29 & $<0.001$ \\
\hline & $\begin{array}{l}\text { Working outside } \\
\text { of home }\end{array}$ & 2 & 3.2 & 61 & 96.8 & & & \\
\hline \multirow[t]{2}{*}{ Family Income } & $\begin{array}{l}<\text { minimum } \\
\text { regional wage }\end{array}$ & 44 & 37.9 & 72 & 62.1 & 3.71 & 1.85 to 7.45 & $<0.001$ \\
\hline & $\begin{array}{l}\geq \text { minimum } \\
\text { regional wage }\end{array}$ & 13 & 14.1 & 79 & 85.9 & & & \\
\hline Family & Poor & 12 & 63.2 & 7 & 36.8 & 5.48 & 2.04 to 14.77 & 0.001 \\
\hline Prosperity & Prosperous & 45 & 23.8 & 144 & 76.2 & & & \\
\hline \multirow[t]{2}{*}{ Residence area } & Rural areas & 54 & 51.9 & 50 & 48.1 & 36.36 & 10.83 to & $<0.001$ \\
\hline & Urban areas & 3 & 2.9 & 101 & 97.1 & & 122.05 & \\
\hline
\end{tabular}

\section{Path Analysis}

Figure 1 shows the structural model of the variables studied. Table 4 shows the results of the pathway analysis of variables affecting other variables, including the use of ANC services influenced by the family welfare $(\mathrm{b}=1.42 ; 95 \% \mathrm{CI}=0.34$ to $2.49 ; \mathrm{p}=$ income $(\mathrm{OR}=2.31 ; \mathrm{p}=0.022)$, family welfare $(\mathrm{OR}=2.46 ; \mathrm{p}=0.089)$ stay $(\mathrm{OR}=$ 1.78; $\mathrm{p}=0.107$ ) improved the provision of complete basic immunization to infants. 
Journal of Maternal and Child Health (2017), 2(4): 371-384

https://doi.org/10.26911/thejmch.2017.02.04.08

CI $95 \%=-0.10$ to2.18; $\mathrm{p}=0.074)$. the income was influenced by the education level $(b=1.21 ; 95 \% \mathrm{CI}=0.50$ to $1.92 ; \mathrm{p}=$ o.001) and occupation $(\mathrm{b}=2.54 ; 95 \% \mathrm{CI}=$ 1.67 to $3.41 ; \mathrm{p}<0.001)$. The welfare was affected by the area of residence $(b=1.4$;

Table 3. The bivariate analysis of the effect of socio-economic factors on the process of giving basic immunization

\begin{tabular}{|c|c|c|c|c|c|c|c|c|}
\hline \multirow{3}{*}{ Variables } & \multirow{3}{*}{ Categories } & \multicolumn{4}{|c|}{ Basic Immunization } & \multirow{3}{*}{ OR } & \multirow{3}{*}{$95 \% \mathrm{CI}$} & \multirow{3}{*}{$\mathbf{p}$} \\
\hline & & \multicolumn{2}{|c|}{ Incomplete } & \multicolumn{2}{|c|}{ Complete } & & & \\
\hline & & $\mathbf{n}$ & $\%$ & $\mathbf{n}$ & $\%$ & & & \\
\hline \multirow{2}{*}{$\begin{array}{l}\text { Educational } \\
\text { background }\end{array}$} & Low & 31 & 31.3 & 68 & 68.7 & \multirow[t]{2}{*}{2.02} & \multirow[t]{2}{*}{1.07 to 3.87} & \multirow[t]{2}{*}{0.045} \\
\hline & High & 20 & 18.3 & 89 & 81.7 & & & \\
\hline \multirow[t]{2}{*}{ Occupation } & Working at home & 44 & 30.3 & 101 & 69.7 & \multirow[t]{2}{*}{3.48} & \multirow[t]{2}{*}{1.47 to 8.25} & \multirow[t]{2}{*}{0.005} \\
\hline & $\begin{array}{l}\text { Working outside } \\
\text { of home }\end{array}$ & 7 & 11.1 & 56 & 88.9 & & & \\
\hline \multirow[t]{2}{*}{ Family income } & $\begin{array}{l}<\text { minimum } \\
\text { regional wage }\end{array}$ & 36 & 31 & 80 & 69 & \multirow[t]{2}{*}{2.31} & \multirow[t]{2}{*}{1.72 to 4.55} & \multirow[t]{2}{*}{0.022} \\
\hline & $\begin{array}{l}\geq \text { minimum } \\
\text { regional wage }\end{array}$ & 15 & 16.3 & 77 & 83.7 & & & \\
\hline \multirow[t]{2}{*}{ Family welfare } & Poor & 8 & 42.1 & 11 & 57.9 & \multirow[t]{2}{*}{2.46} & \multirow[t]{2}{*}{0.93 to 6.53} & \multirow[t]{2}{*}{0.089} \\
\hline & Prosperous & 43 & 22.8 & 146 & 77.2 & & & \\
\hline \multirow[t]{2}{*}{ Residence area } & Rural areas & 31 & 29.8 & 73 & 70.2 & \multirow[t]{2}{*}{1.78} & \multirow[t]{2}{*}{0.94 to 3.4} & \multirow[t]{2}{*}{0.107} \\
\hline & Urban areas & 20 & 19.2 & 84 & 80.8 & & & \\
\hline
\end{tabular}

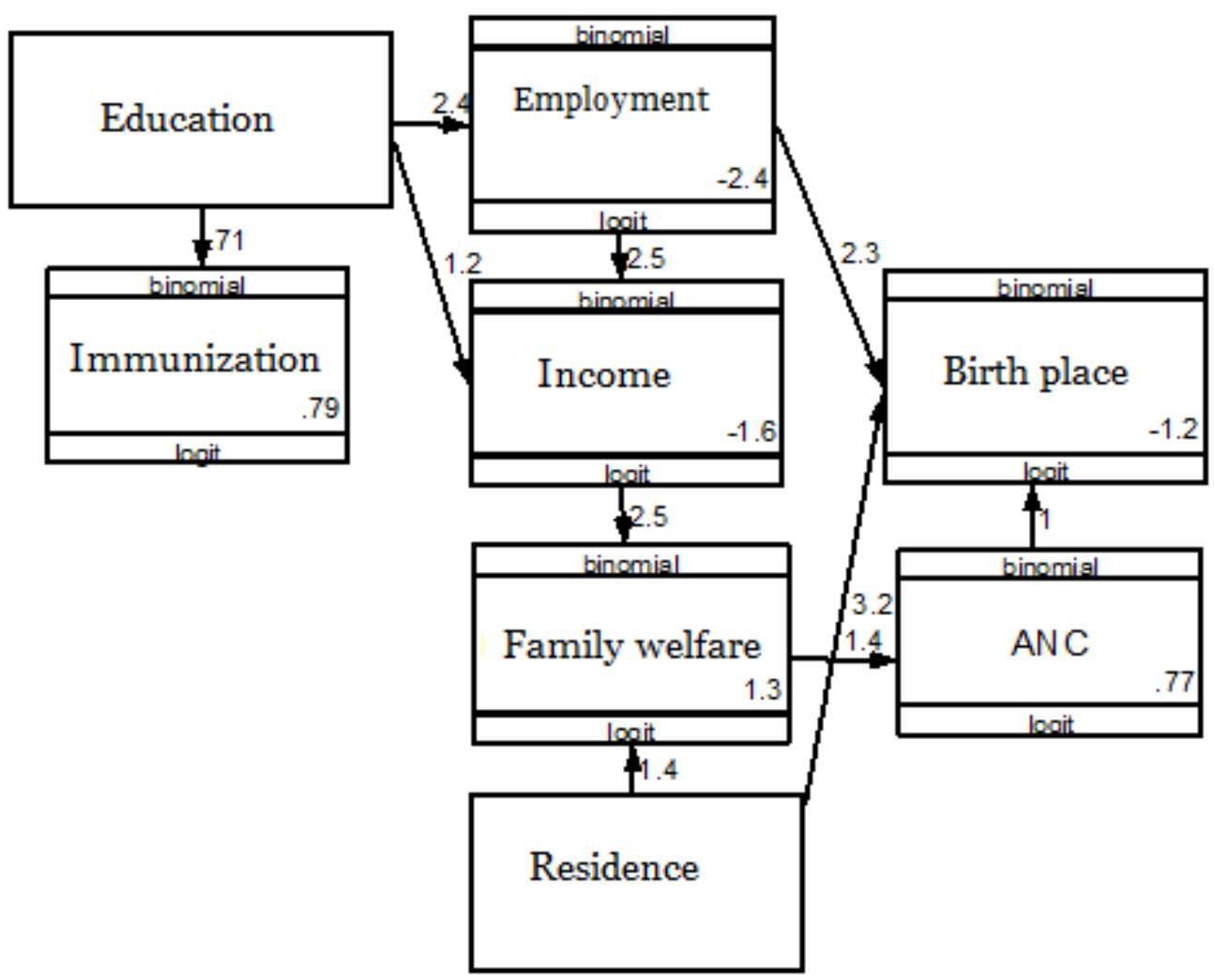

Figure1. Structural model of socio-economic factor path analysis that influences the use of primary health care services in mothers and children 
Table4. The result of path analysis

\begin{tabular}{|c|c|c|c|c|c|}
\hline $\begin{array}{c}\text { Dependent } \\
\text { Variables }\end{array}$ & & $\begin{array}{l}\text { Independent } \\
\text { Variables }\end{array}$ & $\begin{array}{c}\text { Path } \\
\text { Coefficient }\end{array}$ & $95 \% \mathrm{CI}$ & $\mathbf{p}$ \\
\hline \multicolumn{6}{|l|}{ Direct Effect } \\
\hline ANC & $\leftarrow$ & Welfare/prosperity & 1.42 & 0.34 to2.49 & 0.010 \\
\hline Immunization & $\leftarrow$ & Educational & 0.71 & 0.06 to 1.35 & 0.032 \\
\hline Places for birth & $\leftarrow$ & ANC & 1.04 & -0.1 to 2.18 & 0.074 \\
\hline delivery & $\leftarrow$ & Occupation & 2.34 & 0.77 to 3.91 & 0.003 \\
\hline & & Residence areas & 3.2 & $1.97 \mathrm{u}$ to 4.44 & $<0.001$ \\
\hline \multicolumn{6}{|l|}{ Indirect Effect } \\
\hline \multirow{2}{*}{ Family income } & $\leftarrow$ & Occupation & 2.54 & 1.67 to 3.41 & $<0.001$ \\
\hline & $\leftarrow$ & Education & 1.21 & 0.5 to 1.92 & 0.001 \\
\hline \multirow[t]{2}{*}{ Family welfare } & $\leftarrow$ & Family income & 2.5 & 0.44 to 4.54 & 0.017 \\
\hline & $\leftarrow$ & Residence area & 1.4 & 0.09 to 2.68 & 0.035 \\
\hline $\begin{array}{l}\text { Occupation } \\
\text { n Observation }=208 \\
\text { Log Likelihood }=-521 .\end{array}$ & $\leftarrow$ & Education & 2.45 & 1.63 to 3.26 & $<0.001$ \\
\hline
\end{tabular}

\section{DISCUSSIONS}

\section{The effect of family welfare on the use of ANC service}

From the result of the study, it can be seen thatthere was a direct effect which was statistically significant between family welfare and the use of ANC services, which shows that mothers with better family welfare tend to do an ANC check $\geq 4$ times during pregnancy than mothers from poor families.

A prosperous family can afford to pay for medical expenses and health checks.In addition to financing the needs of everyday life, a prosperous family also set up funds or savings for sudden needs. Most prosperous families have health insurance to conduct check up and get family healthcare at all times, both in public and private health facilities, while poor families are reported to have lower health and they are in higher risk of illness because they can not afford health services and health insurance. This leads to short life expectancy and high mortality (Woolf et al., 2015).

Although maternal health care is free of charge, the poverty, unavailability of maternal health care, high transportation costs, difficulties in arranging transporta- tion for health services, and other possibilities showed differences in the use of health services between poor and prosperous family (Ganle et al., 2014).

\section{The effect of maternal education level on the use of ANC services.}

The level of education indirectly affects the use of ANC services through employment and income. The result of this study showed that highly educated mothers are more likely to increase the use of ANC services $\geq$ 4 timesthrough employment and family income $\geq$ minimum wages.

The result of this study showed that there was a positive and significant effect between maternal education level and family income.The higher a person's education level, the greater the chances of finding a job to earn more than the minimum wage. Education is one of the factors that enable women to have economic independence by working outdoors, therefore, they can help to increase family income and productivity (Saripudin, 2008).

Based on the percentage result of sample education level in this study, it is showed that most of mothers have high educational level. Higher education gets a wider opportunity to get better jobs with greater income.Education can increase the 
income, therefore, it enables someone to purchase health investment as well as gain more benefits from new knowledge and technology (Galama \& Kippersluis, 2010). Families with high incomes have a higher awareness in making efforts to maintain health and prevent the illnesses.Those efforts are conducting routine checks, doing things as directed by health personnels, eating nutritious food and maintaining environmental health (Maidartati \& Parsaulin, 2015).

The results showed that there is a positive and significant effect between maternal employment and family income. Mothers who work outside can increase family income compared to the housewives. Mothers who have jobs and incomes, make a great contribution to the welfare of their families and help in sustaining the economic status of the family (Djabu, 2013). Another source said that the income of working mothers contributed for $53.99 \%$ of total family income in a month (Feriyansyah, 2015). This indicates that working mothers can increase family income which can be used to meet household needs, which were originally imposed on husbands as heads of households. With sufficient income, the family will be able to fulfill the primary needs for survival, whether for individual needs and consumption or for the need of certain social services (Pertiwi, 2015).

The result of this study showed that there was a positive and significant effect between family income and family welfare. Family with $\geq$ minimum regional wage are more prosperous. Welfare is the amount of satisfaction derived from the income consumed (Sunarti, 2006). The BKKBN states some factors affecting family welfare, namely income, employment, asset ownership, and savings (Sunarti, 2006). Families who have $\geq$ of MW income, in addition to being able to fulfill their daily needs, they are also capable to have assets and savings.Poverty is the limitations of ability to have a decent life, one of the limitations is in the income, which cause the economic conditions that decrease the family welfare (Isdijoso et al., 2016).

Poor families will have difficulties in fulfilling their daily needs and in getting a decent life. This indicated that family welfare was affected by family income (Amanuturrohim, 2015). A prosperous family can afford the need for preventive and curative services to maintain their health, therefore, they will have the potential to access better health care, including the use of ANC services $\geq 4$ times during the pregnancy in order to detect the risk in pregnancy (Galama \& Kippersluis, 2010)

\section{3 . The effect of residence on the use of ANC services.}

Residential areas indirectly affect the use of ANC services through family welfare. The result showed that mothers who live in urban area are more likely to increase the use of ANC service $\geq 4$ times through their family welfare.

The results showed that there was a positive and significant effect between the mother's residence and the family welfare. This indicated that mothers who live in urban areas are more prosperous than mothers who live in rural areas. The result of this study is in accordance with the data from the MPI (Multidimensional Poverty Index) in 2014, which states that from 105 countries, about $85 \%$ of the multidimensional poor family live in rural areas. MPI estimates that the rural contribute about $70-75 \%$ on the poverty (Alkire et al., 2014).

This indicated that there was a difference between the residence and family welfare. Families who live in urban area have a better economy than families who live in rural areas. The welfare of families 
who live in urban areas is affected by both of husband and wife's employments. The kind of employments provided in urban areas are more diverse and have better salary (Pertiwi, 2015). There is a difference in the employment status between mothers who live in urban and rural areas.Most of the mothers who live in urban area work as employees or office staffs, while mothers who live in rural area mostly work as farmers (Tran et al., 2011).

Working mothers can help to improve the family economy to be more prosperous. A person's welfare status is related to the environment and population of his/her residence, this is because the economic conditions of local communities determine the access to employment, trade, schools and even the health care services and other resources that can affect the welfare of his/her family (Woolf et al., 2015).

Mothers with higher levels of welfare can access and use all the maternal and children health services than mothers from poor families (Ganle etal., 2014). Additionally, mothers with prosperous family have better access to services, one of them is the use of ANC services at WHO standards ( $\geq 4$ times) during the pregnancy (Obiyan \& Kumar, 2015).

\section{The effect of employment on the selections of birth delivery places}

The result showed that there was a direct effect which is statistically significant between maternal employment and the selections of birth delivery places. Working mothers are participated in improving the economy of family. Working mothers can also increase the use of health services including birth deliveries at health facilities, because by working, they can socialize and the awareness of their salary ultimately changes their behaviours (Mahwati, 2013).
Mothers tend to know more about pregnancy and birth delivery because they work outside their houses, besides that, mothers also tend to seek the informations about health cares for pregnant women which is available in the workplace. Working mothers have economic independence, which allow them to have a voice in the family as well as in the community, to manage the costincurred in the family, including the costs of giving birth at health facility(Saripudin, 2008). Working mothers have better ability to access health services than non-working mothers (Sugiharti \& Lestary, 2011).

\section{The effect of residence on the selections of birth delivery places.}

The result of this study showed that there was a direct effect which is statistically significant between the residence and the selections of birth delivery places. Mothers who live in urban areas tend to choose to give birth at health facilities, while mothers who live in rural areas mostly prefer to give birth at home.There are differences in the access and the use of mothers' residence areas. Birth delivery at home is still risky although it is helped by health personnel (Ganle etal., 2014). In addition to geographical location which is far from health facilities, some mothers prefer to give birth at home due to cost factors and also the lack of knowledge about the dangers that can threaten her life (Putri, 2016).

Mothers who live in urban areas prefer to give birth in health facilities than mothers who live in rural areas.The difference between urban and rural areas is in the availability of health facilities. The health facilities which is provided for the mothers who give birth in urban areas are more improved than for the mothers who give birth in rural areas (Kamal et al., 2016). 
Although the mothers often use ANC services, the improvement of health facilities only occured in urban areas. The cultural and family influences also the quality of health facility services in rural areas influenced the mothers to give birth at home (Choe et al., 2016). In addition, cultural factors and family support also affect the mothers who live in rural areas to give birth at home rather than in health facilities (Parenden, 2015).

\section{The effect of the use of ANC services on the selections of birth delivery place}

The result of this study showed that there was a direct effect which is statistically significant between the use of ANC services and the selections of birth delivery places. This indicated that mothers who have done ANC tests $\geq 4$ times during pregnancy preferred to give birth at health facility rather than at home. Regression and metaanalysis results also identify the relationship between ANC tests and birth delivery at health facility (Berhan \& Berhan, 2014).

ANC tests $\geq 3$ times can increase the birth delivery in health facilities. Infant mortality occurred 2 times higher to mothers who conduct ANC tests $<1$ time during pregnancy compared to mothers who conduct ANC tests $\geq 3$ times during pregnancy (Pervin et al., 2012). This is related to the mother's understanding/ knowledge and awareness of health. Mothers who used ANC services $\geq 4$ times during pregnancy are more aware of the health benefits that they receive from routine pregnancy tests and have better knowledge of pregnancy health than mothers who rarely check their pregnancies. The more often the mothers are associated with health personnel and learn about health information, the greater their interest in giving birth in health facilities to avoid the risk of birth delivery at home (Seth et al., 2017).

\section{The effect of educational level on the selections of birth delivery place}

Educational level was indirectly affect the selections of birth delivery places through employment. The results of this study indicate that highly educated mothers have the possibility of improving the selections of birth delivery in health facilities through employment.

The results showed that there was a positive and significant effect between maternal education level and maternal employment.This indicated that mothers with a high level of education mostly prefer to work outside, while mothers with low levels of education prefer to work at home or become housewives.

The level of education allows someone to find a better job that matches his/her knowledge or interest. In effective employment recruitment process, employment opportunities are only provided to qualified persons and skills to meet job specifications, one of them is the education that they have (Setiani, 2013). Highly educated mothers have greater opportunities to work and earn money outside the home. Increased maternal education and employment become a good indicator of the family economic development, because by working, mothers can improve the autonomy in decision making at home in terms of their own health and their family's health. Central Bureau of Statistics, 2012), one of them is to contribute in making decisions to regulate the division of costs incurred by the family. It includes the costs required in delivering the baby at health facility, so that all the needs at the birth delivery time can be prepared. 


\section{The effect of maternal education levels on the provision of complete basic immunization}

The results of the study showed that there was a direct effect which is statistically significant between maternal education levels and complete basic immunization to the baby. The educational level is greatly affect the healthy living behavior, in which formal education will equip a person with the fundamental of knowledge, theory and logic, general knowledge, analytical skills, and personality development. A highly educated person will more quickly to receive messages and information about the benefits of the health services, therefore, it is easier to implement them in his/her daily life.

Looking from the background of maternal education as the subject of this study, it is showed that most of the mothers are high school and college graduates. The higher a person's educational level, the more it will affect the access to information and understanding of a problem that will affect his/her health, such as immunization. The information is obtained from the media, information from close related people (relatives, family and others) and health personnels. The numerous informations obtained from health-supporting matters can improve health and quality of life.

Education can improve cognitive abilities and the use of modern health services. Educated mothers are better to access, understand and respond to health information which is used to improve their child's health in fewer resources.Maternal education level is a key factor on children's development, whether the children living in poor and developing countries are having improved or vulnerable growth(Heaton et al., 2016).
There is a relationship between maternal education level and the complete immunization of the infant (Dewi et al., 2014). Highly educated families are more aware of the health of their families than low-educated families, and it included in providing immunizations to their babies (Rammohan et al., 2012).

\section{REFERENCES}

Alkire S, Chatterjee M, Conconi A, Suman S, Vaz A (2014). Poverty in Rural and Urban Areas Direct comparisons using the global MPI 2014. Oxford Poverty and Human Development Initiative, 1-4

Amanuturrohim H (2015). Pengaruh Pendapatan Dan Konsumsi Rumah Tangga Terhadap Kesejahteraan Keluarga Petani Penggarap Kopi Di Kecamatan Candiroto Kabupaten Temanggung. Economic Education Analysis Journal, 5(2)

Badan Pusat Statistik (2012). Survei Demografi Dan Kesehatan Indonesia. http://chnrl.org/pelatihan-demografi/SDKI-2012.pdf

Bappenas (2013). Health Sector Review Kumpulan Policy Brief Health Sector Review Kumpulan Policy Brief, 1-84.

Berhan Y, Berhan A (2014). Antenatal care as a means of increasing birth in the health facility and reducing maternal mortality: a systematic review. Ethiopian Journal of Health Sciences, 24: 93-104. https://doi.org/10.4314/ejhs.v24i1.9S

Choe S A, Kim J, Kim S, Park Y, Kullaya SM, Kim CY (2016). Do antenatal care visits always contribute to facilitybased delivery in Tanzania? A study of repeated cross-sectional data. Health Policy and Planning, 31(3), 277-284. https://doi.org/10.1093/heapol/czvo 


\section{4}

Dewi AP, Darwin E, Edison (2014). Hubungan Tingkat Pengetahuan Ibu dengan Pemberian Imunisasi Dasar Lengkap pada Bayi di Kelurahan Parupuk Tabing Wilayah Kerja Puskesmas Lubuk Buaya Kota Padang Tahun 2013. Jurnal Kesehatan Andalas, 3(2), 114-118.

Dinas Kesehatan Provinsi Kaltara. (2016).

Data Dinas Kesehatan Provinsi Kalimantan Timur

Dinas Kesehatan Nunukan (2016). Profil Kesehatan 2016. Kabupaten Nunukan Provinsi Kalimantan Utara

Djabu O. (2013). Peranan Ibu Rumah Tangga yang Bekerja dalam Meningkatkan Status Sosial Keluarga di Kelurahan Teling Atas Kecamatan Wanea Kota Manado. https://ejournal.unsrat.ac.id/index.php/actadiurn a/article/viewFile/2333/1887

Feriyansyah E (2015). Pengaruh Pendapatan Suami dan Istri Terhadap Ekonomi Keluarga (Studi Kasus di PT. Pagilaran Unit Kaliboja). Skripsi. Fakultas Ekonomi dan Bisnis Islam Universitas Islam Negeri Walisongo Semarang

Galama T, Kippersluis HV (2010). A Theory of Socioeconomic Disparities in Health over the Life Cycle. CESRSchaeffer Working Paper, 1-49. https://doi.org/10.2139/ssrn.1659905

Ganle JK, Parker M, Fitzpatrick R, Otupiri $\mathrm{E}$ (2014). Inequities in accessibility to and utilisation of maternal health services in Ghana after user-fee exemption: A descriptive study. International Journal for Equity in Health, 13(1). https://doi.org/10.1186/s12939-0140089-z

Heaton TB, Crookston B, Pierce H, Amoateng AY (2016). Social inequality and children's health in Africa: A cross sectional study. International Journal for Equity in Health, 15(1), 1-14. https://doi.org/10.1186/s12939-0160372-2

Isdijoso W, Suryahadi A, Akhmadi (2016). Penetapan Kriteria dan Variabel Pendataan Penduduk Miskin yang Komprehensif dalam Rangka Perlindungan Penduduk Miskin di Kabupaten/Kota, Kertas Kerja SMERU Research Institute

Kamal N, Curtis S, Hasan MS, Jamil K (2016). Trends in equity in use of maternal health services in urban and rural Bangladesh. International Journal for Equity in Health, 15(1), 1-11. https://doi.org/10.1186/s129390160311-2

Kementerian Desa, Pembangunan Daerah Tertinggal dan Transmigrasi Republik Indonesia (2015). Rencana Strategis (Renstra) Direktorat Jenderal Pembangunan Daerah Tertinggal Tahun 2015-2019.

Kementerian Kesehatan RI (2008). Keputusan Menteri Kesehatan RI No. 828/MENKES/SK/IX/2008 tentang Petunjuk Teknis Standar Pelayanan Minimal Bidang Kesehatan di Kabupaten/Kota.https://doi.org/10.1017/CBO9781107415324.004

Kementerian Kesehatan RI (2014). Infodatin Pusat Data dan Informasi Kementerian Kesehatan RI. Pusat Data Dan Informasi Kementrian Kesehatan RI: Penyebab Kematian Ibu. www.depkes.go.id/resources/download/pusdatin/infodatin/infodatin ibu.pdf

Kementerian Kesehatan RI (2016). profil Kesehatan Indonesia. Kesehatan (Vol. 70).https://doi.org/10.1111/evo.12990 Kementerian Kesehatan RI (2017). Data dan Informasi Profil Kesehatan Indo- 
nesia 2016. Kementerian KesehatanRI, 100. Retrieved from http://www.depkes.go.id/resources/download/pu sdatin/lain-lain/Data dan Informasi Kesehatan Profil Kesehatan Indonesia 2016 -smaller size-web.pdf

Mahwati Y (2013). Pemanfaatan Pelayanan Kesehatan Ibu di Jawa Barat Maternal Health Care Utilization in West Java. Jurnal Kesehatan Masyarakat Nasional 7(6)

Maidartati, Parsaulin P (2015). Gambaran Pengetahuan Ibu Hamil Trimester I Tentang Pengaruh Rokok Terhadao Tumbuh Kembang Janin di Poli Kandungan RSUD Kota Bandung. Jurnal Ilmu Keperawatan, III(1), 38-50.

Obiyan M O, Kumar A (2015). Socioeconomic Inequalities in the Use of Maternal Health Care Services in Nigeria: Trends Between 1990 and 2008. SAGE Open, 5(4). https://doi.org/10.1177/2158244015614070

Parenden RD (2015). Analisis Keputusan Ibu Memilih Penolong Persalinan Di Wilayah Puskesmas Kabila Bone. Jurnal Ilmu Kesehatan Masyarakat Unstrat (JIKMU), 5(4).

Pertiwi P (2015). Analisis Faktor-Faktor Yang Mempengaruhi Pendapatan Tenaga Kerja Di Daerah Istimewa Yogyakarta. Skripsi. Fakultas Ekonomi Universitas Negeri Yogyakarta.

Pervin J, Moran A, Rahman M, Razzaque, A, Sibley L, Streatfield PK, Rahman A (2012). Association of antenatal care with facility delivery and perinatal survival - a population-based study in Bangladesh. BMC Pregnancy and Childbirth, 12(1), 1. https://doi.org/10.1186/1471-2393-12-111.

Pusdatin (2016). Estimasi Jumlah Penduduk Indonesia Tahun 2015: Ringkasan Eksklusif Data dan Informasi Kesehatan Kalimantan Utara, Kemen- terian Kesehatan RI

Putri MD (2016). Faktor Faktor Yang Berhubungan Dengan Pemilihan Tempat Persalinan. Jurnal Kesehatan Masyarakat, 4(April), 55-67.

Rammohan A, Awofeso N, Fernandez RC (2012). Paternal education status significantly influences infants measles vaccination uptake, independent of maternal education status. BMC Public Health, 12(1), 1. https://doi.org/10.1186/1471-245812-336

Saripudin D (2008). Pembangunan Pendidikan Dan Pertumbuhan Ekonomi Indonesia, International Seminar on Lifelong Education (ISLE), 1-14.

Seth A, Tomar S, Singh K, Chandurkar D, Chakraverty A, Dey A, Silverman JG (2017). Differential effects of community health worker visits across social and economic groups in Uttar Pradesh, India: A link between social inequities and health disparities. International Journal for Equity in Health, 16(1), 1-9. https://doi.org/10.1186/s12939-0170538-6

Setiani B (2013). Kajian Sumber Daya Manusia Dalam Proses Rekrutmen Tenaga Kerja Di Perusahaan. Jurnal Ilmiah Widya, 1(1), 38-44. Retrieved from http://e-journal.jurwidyakop3.com/index.php/jurnalilmiah/article/view/106.

Sugiharti, Lestary H (2011). Faktor-faktor yang Mempengaruhi Pemanfaatan posyandu/Polindes pada Ibu Hamil di Indonesia. Jurnal Ekologi Kesehatan, 10(2), 65-71.

Sunarti, E. (2006). Indikator Keluarga Sejahtera: Sejarah Pengembangan, Evaluasi, dan Keberlanjutannya, 116. Dr.Euis-Sunarti-Kependudukan-dan-Keluarga-Sejahtera2A.pdf.

Tran TK, Nguyen CTK, Nguyen HD, Eriksson B, Bondjers G, Gottvall K, Petzold 
Journal of Maternal and Child Health (2017), 2(4): 371-384

https://doi.org/10.26911/thejmch.2017.02.04.08

M (2011). Urban-Rural disparities in antenatal care utilization: A study of two cohorts of pregnant women in Vietnam. BMC Health Services Research, 11(1), 120. https://doi.org/10.1186/1472-696311-120

Unicef. (2012). Kesehatan Ibu \& Anak. UNICEF Indonesia, (Gambar 2), 1-2. https://doi.org/9870
Woolf SH, Simon SM, Aron L, Zimmerman

E, Dubay L, Luk KX (2015). How Are Income and Wealth Linked to Health and Longevity? Urban Institute, (April), 1-22. Retrieved from http://www.urban.org/research/publication /how-are-income-and-wealth-linkedhealth-and-longevity 